\title{
ON-FARM INVESTIGATIVE DEVELOPMENT: A PARTNERSHIP BETWEEN FARMERS, CONSULTANTS AND SCIENTISTS
}

\begin{tabular}{|c|c|}
\hline ientist & 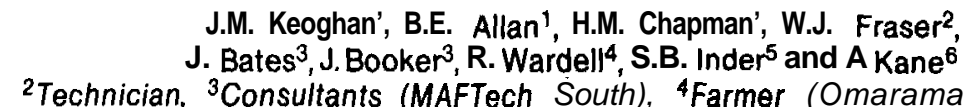 \\
\hline & Irmer (Ardlui Farm, Middlemarch), "Farmer (Glentovle Station, Luggate) \\
\hline
\end{tabular}

Abstract

An on-farm investigative development approach is advocated and described as a relevant method to improve industry awareness and understanding of altemative pasture species and cultivars for South Island hill and high country pastoral systems and thereby improve their currently slow or sporadic rate of adoption. On-fam investigative development trials aim at effectively bridging gaps between plant breeder, agronomist, consultant and famer. They closely integrate research objectives and extension through the establishment of large-scale experiments with pasture plants and pasture systems on farms, in close co-operation with key famers. They are of sound experimental design and yet large enough to be defined as a production system, contributing significantly to the livestock feeding goals of the co-operating famer. Such trials are an integral part of the cc-operative (DSIR/MAF) Lotus corniculatus breeding programme. Three of them, each located in ,a different environmental/geographic zone, are described.

Keywords: Large-scale trials, altemative pasture species, Lotus corniculatus, plant breeding/ plant selection, South Island hill and high country.

\section{INTRODUCTION}

Innovative strategies are required to improve industry (farmers, advisers and seed firms) awareness of the attributes of alternative species and cultivars for South Island hill and high country pastoral systems. This paper considers the slow or sporadic adoption of alternative species and outlines an approach aimed at rectifying this problem.

Most pasture cultivars used in South Island hill and high country pastoral development are conventional species, bred primarily for intensive lowland farming systems. Recently, however, as the limitations of relying on broadly adaptable "national" cultivars over a very wide range of environments and farming systems have been realised, more breeding and selection programmes have focused on the identification and development of plants for specific regions, environments and farming systems (Corkill et al. 1981; Keoghan 1985a). The release of 'Grasslands Tahora' white clover for wet, infertile North Island hill country is tangible evidence of this approach. Similarly, 'Grasslands Maku' lotus (Lotus pedunculatus Cav.) has been identified as a valid lower-input alternative to conventional clovers on moist, acid and infertile tussock grassland soils (Scott \& Mills 1981).

Because of the extreme environmental diversity, more pasture species and cultivars should have a significant role in grazing systems in the South Island hill and high country than elsewhere in New Zealand (Keoghan 1985b). Scott et al. (1985) described the environmental suitability of a wide range of pasture species (conventional, alternative, naturalised and native) for this region and outlined their most suitable farm management roles for meeting livestock feeding goals 
throughout the year. In practice, the potential of alternative pasture species and cultivars to improve the efficiency and cost effectiveness of South Island hill and high country pastoral systems has barely been tapped. Introduction of some new species and cultivars has been marred by misunderstandings about their agronomic attributes and environmental adaptation. Sometimes evaluation work has been insufficient for farmers and consultants to confidently derive such information. Furthermore, traditional links between formal research and on-farm application have not always been good enough to avoid inappropriate use, or poor uptake of alternative species and cultivars

Lancashire (1985) stated that although considerable information has been published in research journals, at conferences and in the agricultural press, largescale demonstrations on commercial units and on-farm experiences are probably more important in increasing the rate of adoption of novel or alternative cultivars, currently used cultivars and other options. Replicated small-plot trials on the other hand have lacked credibility with farmers because of their small size and their possible lack of relevance to practical farm management Another important limitation is that replicates have seldom represented enough of the widely different environments within most hill and high country landscapes.

\section{ON-FARM INVESTIGATIVE DEVELOPMENT}

To bridge the gap between breeder, agronomist, consultant and farmer, an onfarm investigative development approach is advocated. On-farm investigative development trials are designed to meet the following criteria.

They must:

1. Be of sound experimental design to enable the valid production of the following types of information:

(a) the performance of new plant selections, newly released commercial cultivars, or of experimental lines, relative to present options.

(b) the identification and verification of relevant and effective agronomic practices for alternative species and cultivars (e.g. establishment and management techniques).

2. Provide a forage system large enough to contribute significantly to meeting the livestock feeding goals of the co-operating farmer.

3. Be a credible extension tool in the farming community and within farmer discussion groups, to enhance the demand for new species and cultivars and an understanding of effective establishment and management practices for them.

This approach is being used in the cooperative (DSIR/MAF), multi-disciplinary Lotus corniculatus regional breeding programme (Widdup et al, 1987). The objective is to ensure that the industry has a good understanding of Lotus corniculatus when a New Zealand cultivar is released in the early 1990s. To initiate this programme before release of the final cultivar(s), two experimental cultivars were produced: 'Dryland' has resulted from a polycross of "elite" genotypes selected from trials in the dry intermontane basins of Central Otago and the MacKenzie Country and 'Otago Plateau', from elite genotypes selected from an altitudinal sequence of trials on the moist, acid and infertile East Otago Plateau (Fraser et al. 1988).

OMARAMA STATION ON-FARM TRIAL

An estimated 280000 ha of tussock grasslands are below $900 \mathrm{~m}$ in the Upper Waitaki, a high proportion of which are droughty, infertile, weakly structured outwash soils Currently used cultivars of conventional clovers are insufficiently 
drought tolerant to persist on these soils and lucerne cultivars are often no more productive during droughts than the clovers, because many subsoils are sufficiently high in soluble aluminium to be antagonistic to their root development (Douglas et al. 1987). Small-plot trials on the Red Flat area (MacKenzie Soils) of Omarama and Killermont Stations and at the DSIR Mt John Research Station at Tekapo (Widdup et al. 1987) indicated that $L$ corniculatus was a better option for these infertile outwash soils than lucerne and conventional clovers.

A 5.1 ha replicated trial was direct drilled on the Red Flat area of Omarama Station, in September 1987 (Fig. 1). Two replicates had been sprayed with glyphosate and the third unsprayed. Adjacent to the replicated trial area, unreplicated blocks of several grass-legume associations were direct drilled. This on-farm trial forms a major development block of 93 ha (Fig. 2).

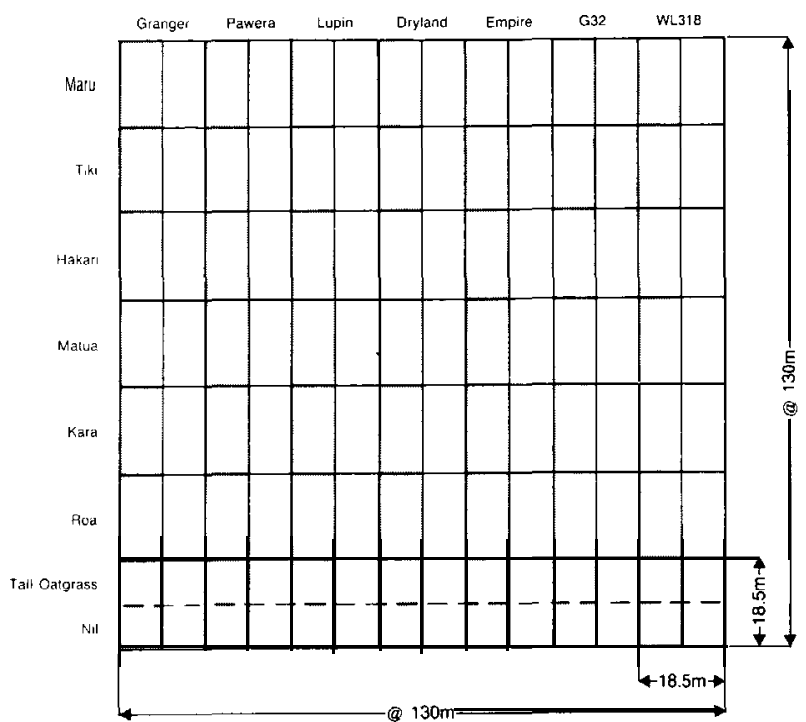

Figure 1: Omarama Station, showing criss-cross design of one replicate. Total replicates: 3 ; total area: 5.1

Shaded area: + phorate insecticide; unshaded area: no phorate.

\begin{tabular}{|l|l|}
\hline L E G U M E S & GRASSES \\
\hline "Dryland" Lotus Cornrculatus & "Grasslands Hakari" Mountain Brome \\
"G32" Lotus Comrculatus & "Grasslands Tiki" Smooth Brome \\
"Empire" Lotus Cornrculatus & "Grasslands Matua" Prairie Grass \\
"Granger" Lotus CorniculatuS & "Grasslands Kara" Cocksfoot \\
"Grasslands Pawera" Red Clover & "Grasslands Roa" Tall Fescue \\
"Connie" Lupin & "Grasslands Maru" Phalaris \\
"WL318" Lucerne & "Mackenzie" Tall Oat Grass \\
\hline
\end{tabular}

\section{Objectives}

1. To investigate and demonstrate the on-farm role of $L$ corniculatus in the development of infertile outwash soils in the Upper Waitaki.

2. To compare the performance of $L$ corniculatus with WL 318 lucerne, 'Grasslands Pawera' red clover and 'Connie' perennial lupin (Lupinus polyphyllus), with and without companion grasses.

3. To compare the performance of Dryland $L$ corniculatus with a North Island selection, G32 and with the North American cultivars, Empire and Granger.

4. To compare the performance of 'Grasslands Kara' and 'Grasslands Wana' 


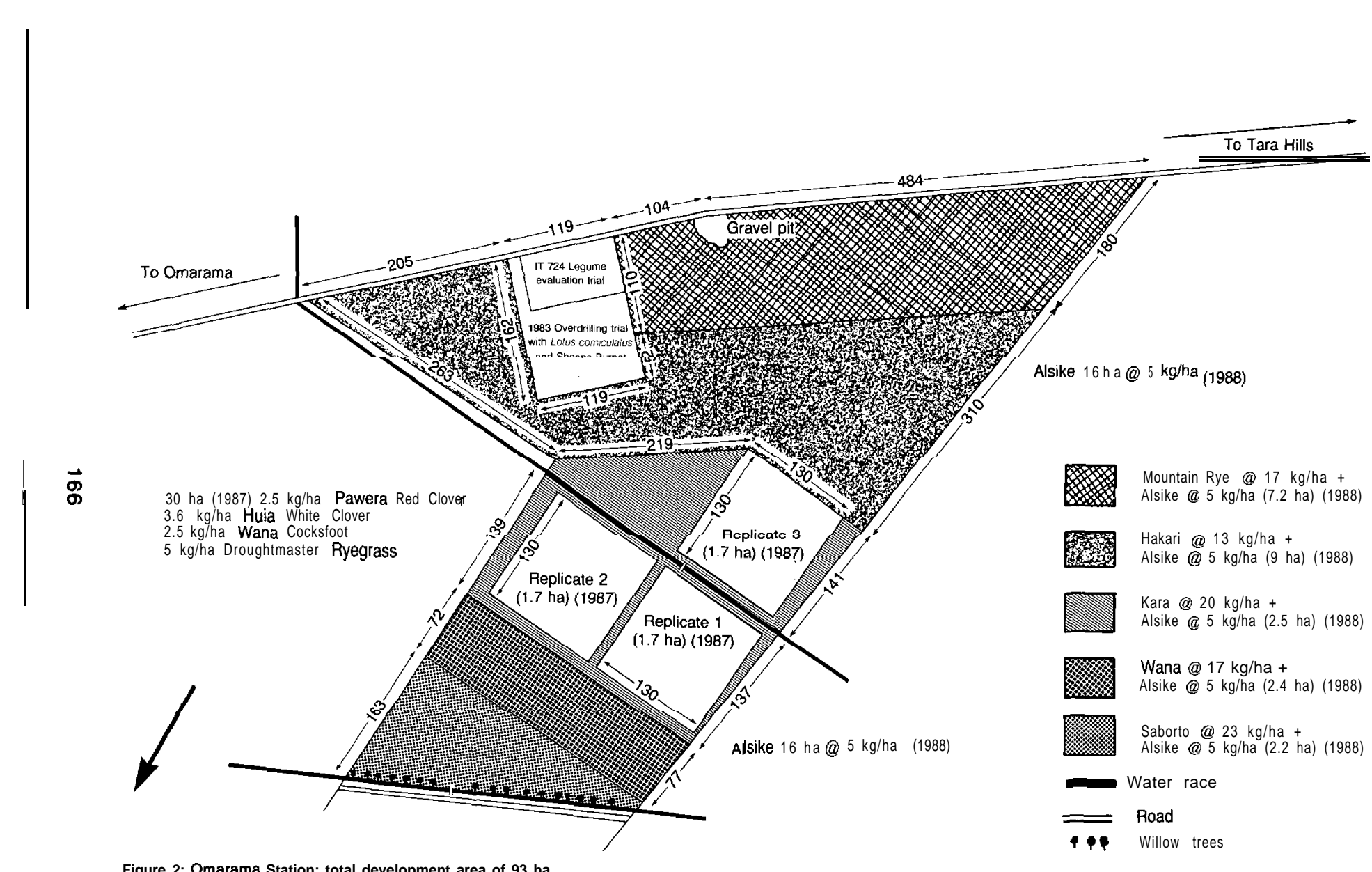


cocksfoots, Saborto cocksfoot, 'Grasslands Maru' phalaris, 'Grasslands Matua' Prairie grass, 'Grassland Hakari' and 'Grasslands Tiki' bromegrasses, Black Mountain mountain rye and McKenzie tall oatgrass, as companion species.

5. To provide guidelines on the effects of phorate insecticide on legume seedling emergence and survival.

6. To provide guidelines on the effect of glyphosate on plant establishment.

7. To Provide guidelines on the performance of alsike clover compared with $L$ corniculatus with and without companion grasses

Prellminary results

Dryland had significantly better establishment than all other legume cultivars and ranked second to Pawera in seedling vigour. Most lucerne and lupin seedlings were unthrifty. Kara had significantly better establishment than the other grasses, the highest grass seedling vigour together with Hakari and tall oatgrass and the highest spring vigour in 1988. Maru had the lowest seedling vigour. Phorate increased legume seedling establishment, by $22 \%$ on average, but in the absence of glyphosate, establishment was extremely poor.

\section{ARDLUI ON-FARM TRIAL}

Conventional clovers lack persistence on the subhygrous yellow-grey earth soils of the Strath Taieri and lucerne is only marginally adapted edaphically. A smallplot trial (Lowther pers. comm.) indicated that $L$ corniculatus could be a more suitable option.

8 A 6.1 ha $L$ corniculatus system was established on Ardlui farm in October 1987, after conventional seedbed preparation. 2.1 ha of the system is a randomised block trial with 3 replicates Surrounding the replicated area are 4 unreplicated blocks of different $L$ corniculatus - grass associations, totalling 4 ha.

Objectives

1. To investigate and demonstrate the role of $L$ corniculatus as a dual-purpose (hay and grazing) legume for the Strath Taieri.

2. To develop a special-purpose forage system for Ardlui.

3. To compare the performance of Dryland $L$ corniculatus with the North American cultivar Granger, with and without a companion grass.

4. To assess the performance of Tiki smooth bromegrass as a companion grass for $L$ corniculatus

5. To assess the effectiveness of Treflan preemergence herbicide.

6 . To provide guidelines on the merit of the North Island $L$ corniculatus selection, G32, compared with Dryland and the North American cultivars Granger and Tana.

7. To provide guidelines on the suitability of Matua prairie grass and 'Grasslands Roa' tall fescue as companion grasses with $L$ corniculatus

Preliminary results

Assessments have shown that G32 and Dryland have established much more successfully than either Granger or Tana, and Tiki smooth brome is showing promise as a compatible companion grass for $L$ corniculatus Matua prairie grass has shown outstanding establishment and cool-season production on this site and Roa tall fescue, excellent establishment and drought tolerance. Treflan has given excellent control of sorrel.

\section{GLENFOYLE STATION ON-FARM TRIALS}

Recent soil tests on Glenfoyle Station have indicated that the disappointing performance of lucerne stands on older terraces in the Upper Clutha may be partly 
attributable to subsoil soluble aluminium levels sufficiently high to be antagonistic to lucerne root development.

A major on-farm trial was direct drilled on an upper terrace area in September 1988, immediately after greenfeed oats. 7.8 ha of the 10 ha paddock has been established in a replicated criss-cross design and the balance in unreplicated blocks.

Objectives

1. To investigate and demonstrate the on-farm role of $L$ corniculatus in the Upper Clutha.

2. To develop a special purpose forage system for Glenfoyle, with greater persistence and versatility than lucerne.

3. To compare the performance of Dryland, G32 and Cascade L corniculatus cultivars with and without companion grasses.

4. To compare the performance of Tiki smooth brome, Hakari mountain brome, and Au Triumph tall fescue as companion grasses for $L$ corniculatus.

5. To provide guidelines on the performance of $G 34$ crown vetch compared with $L$ corniculatus

A smaller development trial on Glenfoyle investigates the role of oversown $L$ corniculatus and Kara cocksfoot for improving the cool-season production from lower sunny faces.

\section{CONCLUSIONS}

The trials on Omarama Station and Ardlui have become important focal points for farmers and farm discussion groups within their respective regions. It is expected that the Glenfoyle trials will achieve the same status in the Upper clutha. This investigative development approach will also be used for defining and promoting the on-farm roles of other promising alternative species such as crown vetch, Dorycnium hirsutum and zigzag and Caucasian clovers, in the continuing search for more cost effective livestock feeding systems in the South Island hill and high country.

\section{Acknowledgements}

The valuable help of D. Brown, R. Abernethy, J. Pedofsky, R. Doney and K Trainer in the establishment of these trials is gratefully acknowledged. The authors also wish to acknowledge Agricom (New Zealand), Challenge Seeds Ltd, Pyne Gould Guinness Ltd, Farmlands Grain New Zealand Society Ltd and Grasslands Division, DSIR for their help with seed supplies.

\section{References}

Corkill, L.; Williams, W.M.; Lancashire, J.A 1981. Pasture species for regions Proceedings NZ Grassland Association 42: 100-22.

Douglas, M.H.: Brash. D.W.; Barratt, B.I.P.; Keoghan J.M. 1987. Successful lucerne growing in inland Otago. Proceedings NZ Grassland Association 48: 192-97.

Fraser, W.J.; Keoghan, J.M.: Heenan, R.P. 1988. Performance of Lotus corniculatus cultivars and lines in an aititudinai sequence on the East Otago Plateau. Proceedings Agronomy Society of NZ 18 (in press).

Keoghan, J.M. 1985a MAF research on alternative pasture species, cultivars and lines for southern South Island hill and high country. Proceedings of the 1985 hill and high country seminar. Centre for Resource Management Special Publication 4: $29-38$.

Keoghan, J.M. 1985b. Fitting pasture species and cultivars into high country landscapes and grazing systems. Proceedings of the 1985 hill and high country seminar. Centre for Resource Management Special Proceedings of the
Publication 4: $51-57$.

Lancashire J.A 1985. Factors affecting the adoption of new herbage cultivars. In Burgess, R.E; Brock, J.L. (Eds) Using herbage cultivars. Grassland Research and Practice Series No. 3, Part IV: $79-87$.

Scott D.: Keoghan. J.M.; Cossens, G.G.; Maunsell, LA; Floate, M.J.S.; Wills, B.J.; Douglas, G. 1985. Limitations to pasture production and choice of species In Burgess, R.E; Brock, J.L. (Eds). Using Herbage Cultivars Grassland Research and Practice Series No. 3. Part I. South Island Hill and High Country: 9-15.

Scott, R.S.; Mills, EG. 1981. Establishment and management of Grasslands Maku lotus in acid, low-fertility tussock grasslands. Proceedings NZ Grassland Association 42: 131-41.

Widdup, KH.: Keoghan. J.M.; Ryan, D.L; Chapman, H. 1987. Breeding Lotus corniculatus for South Island tussock country. Proceedings NZ Grassland Association 48: 119-24. 